\title{
PENDEKATAN BUDAYA MELALUI LANTING MAMA DENGAN PEMBERIAN MAKANAN TAMBAHAN DI DESA PAKU ALAM KECAMATAN SUNGAI TABUK
}

\author{
${ }^{1 *}$ Angga Irawan, ${ }^{2}$ Frimaurora, ${ }^{3}$ Laili Fahriza, ${ }^{4}$ Rini Kresti Sundari \\ ${ }^{1}$ Staff Pendidikan Fakultas Kesehatan, Universitas Sari Mulia Banjarmasin \\ (UNISM) \\ ${ }^{2,3,4}$ Mahasiswa Keperawatan Universitas Sari Mulia Banjarmasin (UNISM) \\ *Email : angga_Irawan10@yahoo.co.id
}

\begin{abstract}
ABSTRAK
Stunting merupakan sebuah kondisi di mana tinggi badan seseorang ternyata lebih pendek dibanding tinggi badan orang lain seusianya yang bersifat kronik pada masa pertumbuhan dan perkembangan sejak awal kehidupan. Menurut Joint Child Malnutrition Estimates tahun 2018-2019, prevalensi balita stunting di dunia sebesar 22,2\% di tahun 2018, dan Menurut Data Dinas Kesehatan Provinsi di tahun 2018 angka kejadian stunting di provinsi Kalimantan Selatan sebesar 28,2\%. Sedangkan menurut data Dinas Kesehatan Kabupaten Banjar tercatat prevalensi balita sangat pendek tercatat sebanyak 13,33\% di tahun 2018. Permasalahan stunting pada anak balita merupakan konsekuensi dari beberapa faktor yang sering dikaitkan dengan kemiskinan termasuk gizi,kesehatan, sanitasi dan lingkungan. Program pemberian makanan tambahan selama 30 hari kepada balita dengan gizi kurang pada program Lanting Mama. Berdasarkan hasil evaluasi yang dilakukan selama 30 hari didapatkan hasil pengukuran berat Badan dari 10 anak mengalami kenaikan Berat Badan (BB) sebesar 7 ons sampai dengan $1 \mathrm{Kg}$. Sedangkan hasil pengukuran Tinggi Badan dari 10 anak semuanya mengalami kenaikan tinggi badan $1-19 \mathrm{~cm}$. Hasil pengukuran Lila anak mengalami kenaikan Lila 0,5 - 1,5 $\mathrm{cm}$. Hasil kegiatan ini menunjukkan bahwa dengan adanya program Lanting Mama dapat membantu dalam meningkatkan berat badan pada anak balita.
\end{abstract}

Kata Kunci: Budaya, Stunting, Makanan Tambahan

\section{A. PENDAhULUAN \\ dunia.}

Stunting merupakan sebuah kondisidi mana tinBgirbastankseseckathag tertolatalebih pendek dib: dunia sebesar 22,2\% di tahun 2017 Overview Child Malnutrition
diperoleh prevalensi stunting
menunjukkan penurunan dari
tahun $2000(32,5 \%)$, tahun 2015
$(23,3 \%)$ dan tahun $2018(21,9 \%)$ penyebab kematian balita di seluruh 
(Pusdatin, 2018). Berdasarkan Data

Dinas Kesehatan Provinsi berdasarkan e-PPGBM (Aplikasi Pencatatan dan Pelaporan Gizi Berbasis Masyarakat) tahun 2018 angka kejadian stunting di provinsi Kalimantan Selatan adalah sebesar $28,2 \%$. Sedangkan menurut data Dinas Kesehatan Kabupaten Banjar tercatat prevalensi balita sangat pendek tercatat sebanyak $13,33 \%$ di tahun 2018, jumlah tersebut mengalami kenaikan dibanding tahun sebelumnya di tahun 2017 yaitu hanya sebanyak 10,63\%. Selain itu, permasalahan dibidang kesehatan di Kabupaten Banjar terlihat dari Data Profil Kesehatan Kabupaten Banjar Tahun 2018 yang menunjukkan angka kematian ibu yang belum mencapai target Sustainable Development Goals (SGDs) yaitu sebesar 70 per 100.000 KH. Sedangkan Angka kematian ibu pada tahun 2017 adalah sebesar 91 per $100.000 \mathrm{KH}$. Permasalahan stunting pada anak balita merupakan konsekuensi dari beberapa faktor yang sering dikaitkan dengan kemiskinan termasuk gizi, kesehatan, sanitasi dan lingkungan. Ada lima faktor utama penyebab stunting yaitu kemiskinan, sosial dan budaya, peningkatan paparan terhadap penyakitinfeksi, kerawanan pangan dan akses masyarakat terhadap pelayanankesehatan.

Faktor sosial dan budaya antara lain meliputi pengetahuan masyarakattentang stunting, pola asuh, perilaku/praktek dan kebiasaan pemberian makanan pada balita. Ada beberapa faktor penyebab masih tingginya kejadian stunting diantaranya adalah penyebab langsung karena kurangnya asupan makanan dan adanya penyakit infeksi. Di samping itu, faktor lainnya adalah kurangnya pengetahuan ibu, adanya kesalahan dalam pola asuh, sanitasi yang kurang memadai dan belum memadainya pelayanan kesehatan serta masyarakat belum menyadari jika anak pendek merupakan masalah.

Program penanganan kasus stunting (gangguan pertumbuhan fisik dan otak pada anak karena kurangnya asupan gizi dalam waktu lama) yang digalakan oleh Kementerian

Kesehatan (Kemenkes), belum dapat memecahkan permasalahan saat ini, khususnya di wilayah Kabupaten Banjar Provinsi Kalimantan Selatan dengan program pemberian 
makanan tambahan (MT) balita melalui pemberian suplementasi gizi makanan tambahan. Selain itu faktor lain yang memengaruhi stunting yaitu perilaku hygiene sanitasi yang kurang baik, terutama hygiene sanitasi makanan. Balita yang mengkonsumsi makanan dengan hygiene sanitasi yang kurang baik dapat mengalami gangguanseperti pengurangan nafsu makan danmuntah-muntah.

$$
\text { Indikator status gizi ini }
$$

berdasarkan indeks TB/U memberikan informasi mengenai indikasi masalah gizi yang sifatnya kronis sebagai akibat dari keadaan yang berlangsung lama. Misalnya: kemiskinan, perilaku hidup tidak sehat, dan pola asuh/pemberian makan yang kurang baik dari sejak anak dilahirkan yang mengakibatkan anak menjadi pendek. Kebutuhan dasar anak untuk tumbuh dapat digolongkan menjadi 3 yaitu asuh, asih, dan asah. Pola asuh Ibu dari kehamilan hingga melahirkan dan 1000 hari pertama kehidupan sangat berpengaruh dalam keadaan gizi dan pertumbuhan anak.

Permasalahan yang muncul di Desa Paku Alam, ada beberapa faktor yang mempengaruhi kejadian stuntingdiantaranya terkait dengan tingkat pendidikan ibu, pengetahuan ibu tentang gizi, pemberian ASI Ekskusif dan umur pemberian makanan pendamping ASI. Selain itu, permasalahan/hambatan dalam upaya pencegahan dan penanggulangan stunting tidak terlepas dari faktor-faktor sosial budaya dan lingkungan dalam masyarakat mereka berada, yang antara lain meliputi pengetahuan budaya dari masyarakat tertentu, adanya kebiasaan danketidaktahuan masyarakat yang bisa berdampak terhadap status gizi anak balita.

\section{B. METODE}

Metode pemecahan masalah yang digunakan pada kegiatan kali ini, sebagai berikut:

1. Melakukan penyuluhan kepada ibu ibu yang mempunyai balita dengan permasalahan dengan stunting di Desa Paku Alam Kecamatan Sungai Tabuk.

2. Pemberian asupan makanan tambahan pada balita yang teridentifkasi masalahan kesehatan dengan stunting. Pelaksanaan kegiatan pengabdian masyarakat ini 
dilakukan selama 30 hari dengan

pemberian makanan tambahan

yang diberikan kepada balita

yang mengalami masalah

stunting setiap hari. Tahap

pelaksanaan dalam kegiatan ini

sebagai berikut:

Gambar.1.Koordinasi dengan

Puskesmas Sungai Tabuk

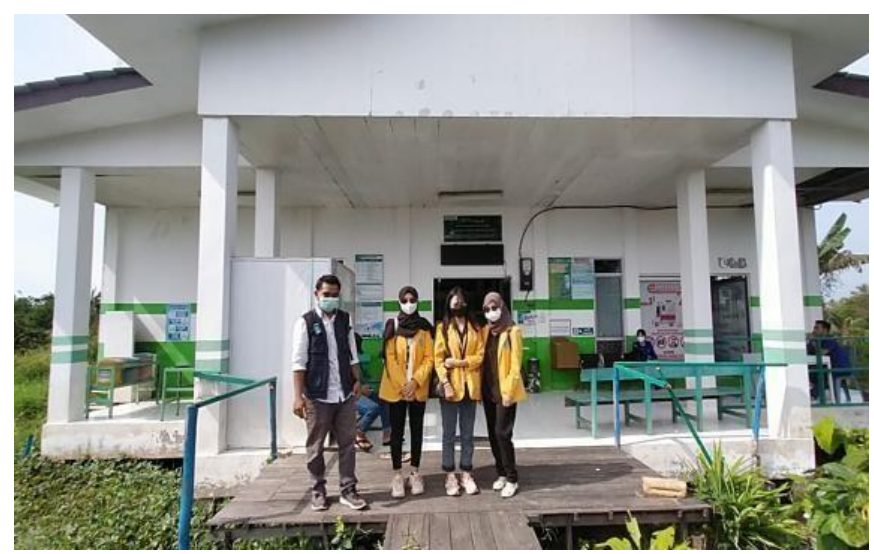

1. Tahap Persiapan

a. Melakukan analisis situasional terkait dengan jumlah sasaran anak balita di Desa Paku Alam Kecamatan Sungai Tabuk

b. Analisis perencanaan kebutuhan terkait dengan pemenuhan gizi, yang dalam hal ini difokuskan kepada balitagizi kurang di Desa Paku Alam Kecamatan Sungai Tabuk

c. Penguatan legalitas kegiatan melalui kemitraan dengan pembekal dan puskesmas dan lingkup implementasi program Lanting Mama.

d. Menyusun Standar

Operating Prosedur (SOP)

Teknis Kegiatan

e. Melakukan sosialisasi kegiatan kepada masyarakat dan teknis kegiatan kepada kader dan petugas kesehatan yang terlibat pada kegiatan

f. Monitoring kegiatan untuk mendapatkan data dan informasi dengan pelaksanaan kegiatan

g. Evaluasi kegiatan

2. Tahap Pelaksanaan

a. Mengumpulkan data jumlah sasaran dan balita gizi

b. Pengadaan Bahan Makanan Lanting Mama"

c. Pendistribusian Lanting Mama

Gambar.2.Tahap Pelaksanaan Program

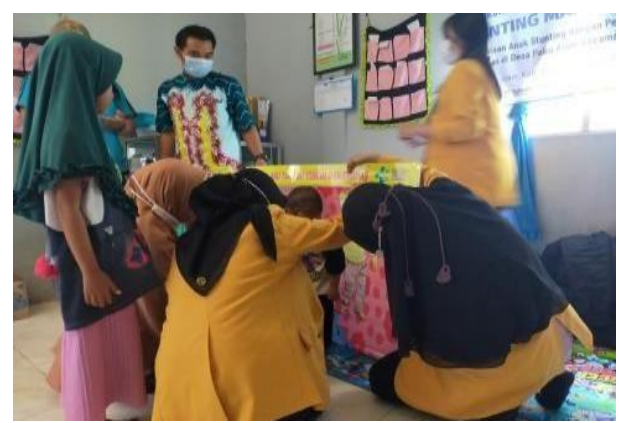

3. Tahap Evaluasi

a. Tim dan Kader memantau pelaksanaan Lanting Mama dan melaporkan kegiatan 
tersebut setiap awal bulan

(minggu pertama) kepada

Puskesmas dan kepala desa.

Laporan berupa, rekapan

jumlah balita gizi kurang

yang mendapatkan program

Lanting Mama dan

kendala/masalah teknis yang dihadapi selama pelaksanaan.

b. Tim dan Kader melakukan monitoring dan evaluasi sesuai format standar atau buku pedoman pemberian gizi kepadabalita gizi kurang.

c. Tim dan Kader melaporkan hasil kegiatan pemberian Lanting Mama ke Dinas Kesehatan kabupaten melalui kepala puskesmas.

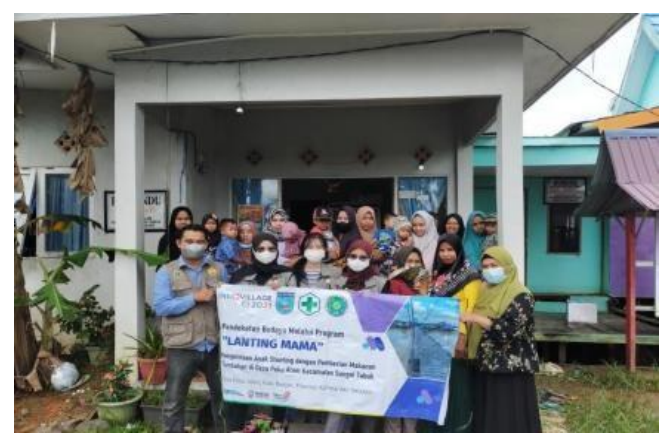

\section{HASIL DAN PEMBAHASAN}

Stunting merupakan sebuah kondisi di mana tinggi badan seseorang ternyata lebih pendek dibanding tinggi badan orang lain seusianya yang bersifat kronik pada masa pertumbuhan dan perkembangan sejak awal kehidupan.

Permasalahan stunting pada balita di Desa paku alam dipengaruhi oleh beberapa faktor diantaranya; 1) tingkat pendidikan ibu, 2) pengetahuan ibu tentang gizi, pemberian ASI Ekskusif, 3) umur pemberian makanan pendamping ASI, 4) faktor sosial budaya dan 5) lingkungan serta 6) status gizi anak balita.

Upaya pencegahan dan pengedalian dalam penangganan stunting dilakukan dengan sebutan program lanting mama yang merupakan suatu tindakan sistematis dan terencana yang dilakukan secara bersama sama oleh intitusi pendidikan, pelayanan kesehatan, pemangku kebijakan, dan tokoh untuk meningkatkan kualitas kesehatan sehingga indikator keberhasilan secara optimal.

Pelaksanaan program lanting mama dilaksanakan selama 30 hari dengan pemberian makanan tambahan yang dilakukan setiap hari. Sedangkan hasil evaluasi kegiatan sebagai berikut: 
Tabel 1. Distribusi Frekuensi Berdasarkan Berat Badan BalitaUsia $12-59$ bulan $(\mathrm{n}=10)$.

\begin{tabular}{ccc}
\hline Berat Lahir & f & \% \\
\hline$<2.500$ Gram & 3 & $30 \%$ \\
\hline$\geq 2.500$. Gram & 7 & $70 \%$ \\
\hline Jumlah & 10 & 100 \\
\hline
\end{tabular}

Distribusi berat badan lahir anak usia 12-59 bulan di Desa Paku Alam Kabupaten Banjar tahun 2021 secara rinci disajikan pada table 1.Terdapat 10 balita dengan kategori Berat badan rendah sebanyak 3balita $(30 \%)$, sedangkan dengan berat badan lahir normal terdapat 7 balita (70\%).

Berdasarkan hasil penelitian menunjukkan Menurut Proverawati \& Ismawati (2010) berat lahir rendah dapat disebabkan oleh faktor ibu, faktor janin, dan faktor lingkungan. Faktor ibu meliputi umur ibu, jarak kelahiran terlalu dekat, status gizi, kehamilan kembar, paritas, status ekonomi, pendidikan, dan pekerjaan ibu.

Hal ini akan menjadi beban pembangunan kesehatan baik jangka pendek maupun jangka panjang. Dampak jangka pendeknya adalah meningkatnya jumlah kematian balita usia 12-59 bulan, sedangkan jangka panjangnya adalah risiko timbulnya beberapa jenis penyakit pada usia dewasa. Dengan demikian kejadian stunting dapat menimbulkan berbagai akibat yang berkaitan dengan peningkatan kualitas bangsa dimasa depan maka perlu upaya untuk menurunkan angka stunting.

Tabel 2. Distribusi Frekuensi Berdasarkan Status Gizi Menurut Indeks TB/U Pada Balita Usia 12- 59 bulan $(n=10)$.

\begin{tabular}{lcc}
\hline Status Gizi & f & $\mathbf{\%}$ \\
\hline Sangat Pendek & 2 & 20 \\
\hline Pendek & 3 & 30 \\
\hline Normal & 5 & 50 \\
\hline Jumlah & 10 & 100 \\
\hline
\end{tabular}

Hasil pengkajian menunjukkan bahwa status gizi anak usia 12-59 bulan di Desa Paku Alam tahun 2021. Berdasarkan indeks TB/U sebagian besar (50\%) dengan berkategori normal. Prevalensi stunting dengan kategori pendek sebanyak $(30 \%)$ dan sangat pendek sebanyak (20\%).

Stunting merupakan status gizi yang didasarkan pada indeks panjang badan menurut umur $(\mathrm{PB} / \mathrm{U})$ sehingga berat badan 
tidak secara langsung

berhubungan dengan indeks

stunting. Meskipun demikian

berat badan lahir yang

merupakan karakteristik bayi

tidak terpisahkan dengan panjang

badan lahir sehingga berat lahir dapat mempengaruhi

pertumbuhan tinggi badan anak

khususnya pada awal periode neonatal.

Menurut Motta, et al., (2005) menyebutkan bahwa faktor risiko penting terhadap status gizi setahun pertama kehidupan anak. Sedangkan Menurut Rahmawati, Nurmawati, \& Sari,) menyebutkan bahwa bayi BBLR akan berisiko tinggi pada morbiditas, kematian, penyakit infeksi, kekurangan berat badan dan stunting diawal periode neonatal.

Bagaimanapun juga gizi kurang merupakan masalah kesehatan yang bukan saja berakibat pada terjadinya masalah kesehatan bayi dalam jangka pendek seperti terjadi komplikasi BBLR tetapi juga berdampak pada kesehatan jangka panjang mulai dari hambatan pertumbuhan sampai dengan meningkatnya risiko berbagai penyakit seperti jantung koroner, diabetes dan kelainan metabolik (Olsa, Sulastri, \& Anas, 2018). Melihat betapa seriusnya akibat dari BBLR maka perlu berbagai upaya untuk mengejar pertumbuhan normal (catch-up growth) dalam waktu yang singkat sehingga tidak sampai berakibatpada kejadian stunting.

\section{Kesimpulan}

Berdasarkan hasil penelitian menyimpulkan bahwa prevalensi stunting pada anak usia 12-59 bulan di Desa Paku Alam adalah 30\% prevalensi BB pada anak usia 12-59 bulan di Desa Paku Alam Hasil pelaksanaan kegiatan pengabdian dapat disimpulkan bahwa dengan adanya program lanting mama sebagai salah satu program yang bisa dilakukan dalam upaya pencegahan dan pengendalian kejadian stuntingpada anak usia 1259 bulan di Desa Paku Alam tahun 2021.

Berdasarkan kegiatan pengabdian kepada masyarakat tersebutmenyarankan kepada Dinas Kesehatan agar dapat meningkatkan 
upaya pemantauan pertumbuhan

Balitakhusunya dalam pemeriksaan dan pengukuran secara berkala panjang badan balita yang pelaksanaannya diintegrasikan dalam kegiatan penimbangan Balita di Posyandu.

Selain itu perlu juga penguatan upaya pencegahan terjadinya stunting dengan memberikan perhatian yang lebih besar pada program-program perbaikan gizi ibu, bayi dan anak.

\section{DAFTAR PUSTAKA}

Gafur, A., Azwar, M., \& Yulis, D. M. (2020). Pengetahuan Ibu Balita Dalam Pengendalian Stunting Di Sulawesi Selatan. UNM Environmental Journals, 3(2), 60-68.

Kemenkes RI, (2010). Keputusan menteri kesehatan RI No. 1995/Menkes/SK/ XII/2010 tentang Standar Antropometri Penilaian Status Gizi Anak Laili, U., \& Andriani, R. A. D. (2019). Pemberdayaan Masyarakat Dalam Pencegahan Stunting. Jurnal Pengabdian Masyarakat IPTEKS, 5(1), 8-12.

Olsa, E. D., Sulastri, D., \& Anas, E. (2018). Hubungan sikap dan pengetahuan ibu terhadap kejadian stunting pada anak baru masuk Sekolah Dasar di kecamanatan Nanggalo. Jurnal Kesehatan Andalas, 6(3), 523529.

Sulistyawati, A. (2018). Faktor-faktor yang berhubungan dengan kejadian stunting pada balita. Jurnal Ilmu Kebidanan, 5(1), 21-30.

Ningtyas, Y. P., Udiyono, A., \& Kusariana, N. (2020). Pengetahuan Ibu Berhubungan Dengan Stunting Pada Balita Di Wilayah Kerja Puskesmas Karangayu Kota Semarang. Jurnal Kesehatan Masyarakat (Undip), 8(1), 107-113.

Uliyanti, U., Tamtomo, D. G., \& Anantanyu, S. (2017). Faktor yang berhubungan dengan kejadian stunting pada balita usia 24-59 bulan. Jurnal Kesehatan Vokasional, 3(2), 13-9.

Rahmawati, A., Nurmawati, T., \& Sari,L. P. (2019). Faktor yang Berhubungan dengan Pengetahuan Orang Tua tentang Stunting pada Balita. JurnalNers dan Kebidanan (Journal of Ners and Midwifery), 6(3), 389395.

WHO, (2010). Nutrition Landscape Information System (NLIS) Country Profile: Indicators Interpretation Guide. WHO Document Production Services, Geneva, Switzerland. 